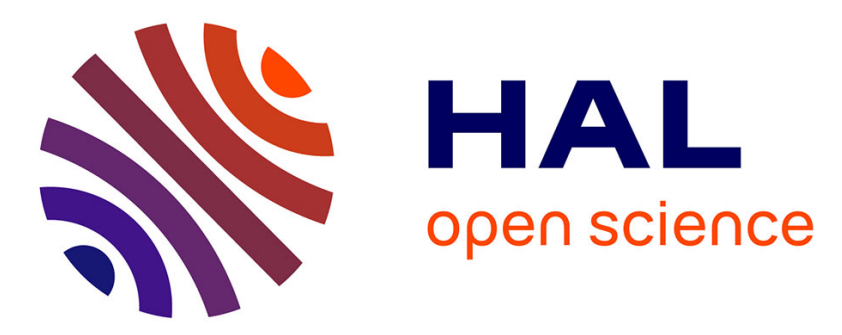

\title{
Differential bioaccumulation of 134 Cs in tropical marine organisms and the relative importance of exposure pathways
}

Marc Metian, Simon Pouil, Laetitia Hédouin, François Oberhänsli, Jean-Louis Teyssié, Paco Bustamante, Michel Warnau

\section{To cite this version:}

Marc Metian, Simon Pouil, Laetitia Hédouin, François Oberhänsli, Jean-Louis Teyssié, et al.. Differential bioaccumulation of $134 \mathrm{Cs}$ in tropical marine organisms and the relative importance of exposure pathways. Journal of Environmental Radioactivity, 2016, 152, pp.127-135. hal-01330652

\section{HAL Id: hal-01330652 https://hal.science/hal-01330652}

Submitted on 12 Jun 2016

HAL is a multi-disciplinary open access archive for the deposit and dissemination of scientific research documents, whether they are published or not. The documents may come from teaching and research institutions in France or abroad, or from public or private research centers.
L'archive ouverte pluridisciplinaire HAL, est destinée au dépôt et à la diffusion de documents scientifiques de niveau recherche, publiés ou non, émanant des établissements d'enseignement et de recherche français ou étrangers, des laboratoires publics ou privés. 


\section{Differential bioaccumulation of ${ }^{134} \mathrm{Cs}$ in tropical marine organisms and the relative importance of exposure pathways}

Marc Metiann $^{\mathrm{a}}$, Simon Pouil ${ }^{\mathrm{a}, \mathrm{b}}$, Laetitia Hédouin ${ }^{\mathrm{a}, 1}$, François Oberhänslia ${ }^{\mathrm{a}}$, Jean-Louis Teyssiéa ${ }^{\mathrm{a}}$, Paco Bustamante ${ }^{\mathrm{b}}$, Michel Warnau ${ }^{\mathrm{a}}$

a International Atomic Energy Agency - Environment Laboratories, Radioecology Laboratory, 4, Quai Antoine Ier, MC-98000, Principality of Monaco, Monaco

b Littoral Environnement et Sociétés (LIENSs), UMR 7266, CNRS-Université de La Rochelle, 2 rue Olympe de Gouges, F-17000 La Rochelle, France

* Corresponding author: Dr Marc Metian

Radioecology Laboratory

IAEA Environment Laboratories

4a Quai Antoine 1er

MC-98000 Principality of Monaco

Telephone: +37797977217

E-mail:m.metian@iaea.org

1 Present address: USR 3278 CNRS-EPHE-UPVD CRIOBE, Laboratoire d'Excellence CORAIL, BP1013, 98729 Papetoai, Moorea, French Polynesia. 
Abstract: Bioaccumulation of ${ }^{134} \mathrm{Cs}$ was determined in 5 tropical marine species: three bivalves (the oysters Isognomon isognomum and Malleus regula, and the clam Gafrarium pectinatum), one decapod (shrimp Penaeus stylirostris) and one alga (Lobophora variegata). Marine organisms were exposed to the radionuclides via different pathways: seawater (all of them), food (shrimp and bivalves) and sediment (bivalves). Our results indicate that the studied tropical species accumulate Cs similarly than species from temperate regions whereas retention capacities seems to be greater in the tropical species. Bioaccumulation capacities of the two oysters were similar for all the exposure pathways. The alga, and to a lesser extent the shrimp, concentrated dissolved Cs more efficiently than the bivalves (approx. 14 and 7 times higher, respectively). Assimilation efficiencies of $\mathrm{Cs}$ in bivalves and shrimp after a single feeding with radiolabelled food were comprised between $7.0 \pm 0.4$ and $40.7 \pm 4.3 \%$, with a variable retention time (half-life $-\mathrm{Tb}_{1 / 2}$ - ranging from $16 \pm 3$ to $89 \pm 55 \mathrm{~d}$ ). Although the clam lives buried in the sediment, this exposure pathway resulted in low bioaccumulation efficiency for sedimentbound Cs (mean transfer factor: $0.020 \pm 0.001$ ) that was lower than the two oyster species, which are not used to live in this media $(0.084 \pm 0.003$ and $0.080 \pm 0.005)$. Nonetheless, Cs accumulated from sediment was similarly absorbed $(61.6 \pm 9.7$ to $79.2 \pm 2.3 \%)$ and retained $\left(\mathrm{Tb}_{1 / 2}: 37 \pm 2\right.$ to $\left.58 \pm 25 \mathrm{~d}\right)$ for the three bivalves species. Despite the poor transfer efficiency of Cs from food, the use of a global bioaccumulation model indicated that the trophic pathways was the main uptake route of Cs in the bivalves and shrimp. In shelled organisms, shells played a non-negligible role in Cs uptake, and their composition and structure might play a major role in this process. Indeed, most of the Cs taken up from seawater and sediment was principally located on the hard parts of the bivalves and shrimp, with the exception of G. pectinatum, where Cs was mainly distributed in the soft-parts.

Keywords: Bivalve; Alga; Shrimp; Radionuclide; Biokinetics 


\section{Introduction}

Since the 1950s, marine ecosystems were sporadically subjected to the release of radionuclides (such as ${ }^{134} \mathrm{Cs}$ ) from industries, nuclear accidents and fallout from nuclear weapon testing (Friedlander et al., 2005). Although this radioactive contamination has tended to decrease (e.g. Ito et al., 2003), it is still a concern in coastal areas receiving radioactive inputs. Marine biota can be directly impacted by waterborne contamination. It was particularly true after the accident that occurred in the civilian nuclear power plant of Fukushima where an important amount of radioactive Cs was released in the marine environment (Bailly du Bois et al., 2012; Chino et al., 2011). After this accident, Cs isotope concentrations increased by up to $10 \mathrm{e} 1000$ times over prior levels in coastal waters off Japan (Buesseler et al., 2012).

Studies on Cs accumulation in marine biota have been subjected to many field investigations. These studies provided some clues of Cs accumulation capacities of bivalves and fish (e.g. Kawai et al., 2013; Rowan and Rasmussen, 1994) using metrics such as field concentration factors or ecological half-lives. However, until now, mechanisms explaining high accumulation capacities reported for certain marine organisms have yet to be unraveled (Hamada and Ogino, 2012; Buesseler, 2012). Hence, levels reported from the field and questions about contamination pathways or depuration capacities of contaminated organisms need to be investigated further.

Laboratory characterizations of bioaccumulation parameters under controlled conditions are key to better understand the significance of field measurements and some studies already highlighted the importance of some factors (e.g., salinity, temperature, individual size/age) that influence Cs bioaccumulation (Carlson and Erlandsson, 1991; Ke et al., 2000; Topcuoğlu, 2001) or the relative importance of the different exposure pathways (e.g. Metian et al., 2010). Indeed, laboratory studies allow (1) comparing the bioaccumulation capacities of different 
marine organisms in fairly comparable contamination conditions, (2) informing about food chain transfer, (3) delineating the major uptake pathway(s) through computation of the data, and (4) providing a clear insight of major biological mechanisms that are activated during pollution events. In the past, a series of experimental studies have investigated the bioaccumulation of radio-cesium in different phyla (e.g. Bustamante et al., 2006; Hattink et al., 2009; Warnau et al., 1996a) focusing on food and/or seawater exposures. Some of these works suggested that Cs might be potentially biomagnified through marine food chain (e.g. Mathews and Fisher, 2008; Mathews et al., 2008; Zhao et al., 2001). Although few studies have tested the contribution of sediment in the global accumulation (Børretzen and Salbu, 2009; Bustamante et al., 2006; Metian et al., 2011), limited knowledge about Cs transfer from sediments is available.

Due to the documented influence of temperature on the Cs uptake (Carlson and Erlandsson, 1991; Ke et al., 2000; Topcuoğlu, 2001), bivalves from tropical regions are expected to accumulate more Cs than those from temperate regions. However, limited information is available on radio-cesium bioaccumulation in tropical areas, although previous radioactive contamination events have occured there (e.g. Mittelstaedt et al., 1999). Furthermore, no information is available regarding the relative importance of the uptake pathways in these warmer areas.

In this context, the aim of the present study was to investigate the bioaccumulation of Cs in tropical marine organisms via different exposure pathways (seawater, food, and sediment): the bivalves Gafrarium pectinatum (previously called Gafrarium tumidum), Isognomon isognomum and Malleus regula, the Pacific blue shrimp Penaeus stylirostris and the brown alga Lobophora variegata. When more than one exposure pathways was investigated, we also assessed the relative contribution of these pathways. 


\section{Materials and methods}

\subsection{Sampling and acclimation}

All the organisms examined originated from NewCaledonia. The Pacific blue shrimps $P$. stylirostris were obtained from the Ifremer experimental farm (Station d'Aquaculture Ifremer de Saint-Vincent, New Caledonia) in 2002. The clams G. pectinatum were collected by seashore fishing in Dumbéa Bay $\left(22^{\circ} 11^{\prime} 2.50^{\prime}\right.$ 'S, $\left.166^{\circ} 24^{\prime} 3.80^{\prime \prime} \mathrm{E}\right)$, the two oysters $I$. isognomum and $M$. regula and the brown alga, L. variegata were collected by SCUBA diving in Maa Bay $\left(22^{\circ} 12^{\prime}, 0.29^{\prime \prime} \mathrm{S}, 166^{\circ} 19^{\prime} 0.42^{\prime \prime} \mathrm{E}\right)$ in 2002 .

All the organisms were then shipped to IAEA-EL premises in Monaco, where they were acclimated to laboratory conditions (open circuit, 400-3000-L aquaria, water renewal: $30 \% \mathrm{~h}^{-}$ ${ }^{1}$; $\mathrm{T}^{\circ}: 25 \pm 0.5^{\circ} \mathrm{C}$; salinity: 36 p.s.u.; $\mathrm{pH}: 8.0 \pm 0.1$; light/dark cycle: $12 \mathrm{~h} / 12 \mathrm{~h}$ ) for 2 months prior to experiments. During this period, clams and oysters were fed daily a mixed algal diet (Isochrysis galbana, Heterocapsa triquetra, Thalassiosira pseudonana, Emiliania huxleyi; total cell density: $10^{4}$ cells $\mathrm{mL}^{-1}$ ) and shrimps were fed daily precooked mussels (Mytilus edulis).

\subsection{Radiotracer and counting}

Uptake and depuration kinetics of ${ }^{134} \mathrm{Cs}$ in orgnisms were determined using a high-specific activity radiotracer purchased from Isotope Product $\mathrm{Lab}\left({ }^{134} \mathrm{CsCl} 0.1 \mathrm{~N}, \mathrm{~T} 1 \frac{1}{2}=2\right.$ years $)$. Tracer was counted using a high-resolution $\gamma$-spectrometer system composed of 5 Germanium $(\mathrm{N}$ - or P-type) detectors (EGNC 33-195-R, Canberra ${ }^{\circledR}$ and Eurysis ${ }^{\circledR}$ ) connected to a multi-channel analyzer and a computer equipped with a spectra analysis software (Interwinner $\left.{ }^{\circledR} 6\right)$. The radioactivity was determined by comparison with standards of known activity and of appropriate geometry. Measurements were corrected for counting efficiency and physical 
radioactive decay. The counting time was adjusted to obtain a propagated counting error less than 5\% (Rodriguez y Baena et al., 2006; Metian et al., 2008).

\subsection{Experimental procedure}

Independent experiments were carried out to investigate Cs bioaccumulation in three bivalve species, one decapod crustacean and one alga. Depending on the species, one to three different exposure pathways were studied: seawater, food and sediment. Details of the experimental conditions are provided in Table 1. In all experiments, for individual recognition, bivalves were tagged on the shell, alga and shrimp were kept individually in a cylindrical PVC container (160 mm height X $80 \mathrm{~mm}$ diameter) covered above and below with $300-\mathrm{mm}$ mesh size net (to allow free water circulation).

\subsubsection{Seawater exposure}

For each species, ten to twenty two individuals were placed in $70-\mathrm{L}$ glass aquaria $\left(\mathrm{T}^{\circ}: 25 \pm\right.$ $0.5^{\circ} \mathrm{C}$; salinity: 36 p.s.u.; pH: $8.0 \pm 0.1$, light/dark cycle: $\left.12 \mathrm{~h} / 12 \mathrm{~h}\right)$. Organisms were exposed from $24 \mathrm{~d}$ (for the shrimps) to $28 \mathrm{~d}$ (for the other species) to the ${ }^{134} \mathrm{Cs}$ radiotracer with a nominal activity of $1-1.6 \mathrm{kBq} \mathrm{L}^{-1}$ (added radiotracer was dissolved in $0.45-\mathrm{mm}$ filtered seawater according to the method described by Warnau et al., 1996b). Seawater exposures were realized in close-circuit aquaria constantly aerated. For each experiment, no change in $\mathrm{pH}$ was detectable after tracer addition.In order to keep radioactivity in seawater as constant as possible, seawater and spike were daily renewed during the first two weeks, then every second day. Activity of the radiotracer in seawater was checked daily, and before and after each spike renewal in order to calculate time-integrated activities $\left(1.14 \pm 0.19 \mathrm{~Bq} \mathrm{~mL}^{-1}\right.$ to $\left.1.62 \pm 0.13 \mathrm{~Bq} \mathrm{~mL}^{-1}\right)$. Immediately before each renewal of seawater and spike, bivalves and shrimps were fed briefly (30 min) with mixed algal diet $\left(10^{4}\right.$ cells $\left.\mathrm{L}^{-1}\right)$ and mussels (ad libitum), respectively, in clean - 
unspiked - seawater. For each experiment, organisms were collected at different time intervals to be whole-body radio-analyzed. For bivalves, some organisms $(n=3)$ were sacrificed at the same time intervals for dissection and determination of ${ }^{134} \mathrm{Cs}$ distribution between soft-parts and shells. At the end of the exposure period, 3 to 5 individuals of bivalves and shrimps were sacrificed for fine dissection (up to 5 body compartments for shrimp). Each body compartment was then weighed and radioanalyzed and activities of these compartments were summed up in order to get compartments presented in Table 3 and to determine ${ }^{134} \mathrm{Cs}$ body distribution. The remaining animals ( $\mathrm{n}=7-10$ per species) were then placed in non-contaminating conditions (open circuit, water renewal: $50 \mathrm{~L} \mathrm{~h}^{-1}, \mathrm{~T}^{\circ}: 25 \pm 0.5^{\circ} \mathrm{C}$; salinity: 36 p.s.u.; $\mathrm{pH}$ : $8.0 \pm 0.1$, light/dark cycle: $12 \mathrm{~h} / 12 \mathrm{~h}$ ) for $43 \mathrm{~d}$ (shrimp) to $59 \mathrm{~d}$ (bivalves and alga) in order to follow the depuration kinetics of ${ }^{134} \mathrm{Cs}$ from the organisms. Three individuals of each species (except for $I$. isognomum) were collected at the end of the depuration period and dissected as previously described.

\subsubsection{Food experiments}

Preparation of the radiolabelled food for shrimp was carried out by exposing commercial mussels (M. edulis) for 3 weeks via natural seawater spiked with $3 \mathrm{kBq}{ }^{134} \mathrm{Cs}^{-1}$. For the bivalves, phytoplankton (I. galbana) was exposed for $6 \mathrm{~d}$ to the radiotracer in a 5-L glass Erlenmeyer using the same activity as the one used for the seawater exposure experiment (viz. $\left.1.6 \mathrm{kBq} \mathrm{L}^{-1}\right)$. At the end of the exposure period, phytoplankton was centrifuged at $2500 \mathrm{~g}$ for 20 min in a Sorvall® RC28S ultracentrifuge, then re-suspended in clean seawater and the cell density was counted. The radioactivity of I. galbana and its spiked mediumwas g-counted before and after the cellular centrifugation.

Ten to twenty individuals of bivalves and shrimp were placed in $50 \mathrm{~L} \mathrm{~h}^{-1}, \mathrm{~T}^{\circ}: 25 \pm 0.5^{\circ} \mathrm{C}$; salinity: 36 p.s.u.; pH: $8.0 \pm 0.1$, light/dark cycle: $12 \mathrm{~h} / 12 \mathrm{~h}$ ). After one week of acclimation in 
these aquaria, organisms were allowed feeding on radiolabelled food $(2 \mathrm{~h}$ for bivalves; $3 \mathrm{~h}$ for shrimp; pulse-chase feeding method; see e.g. Metian et al., 2009, 2010). In parallel, nonexposed individuals of shrimp and empty shells of bivalves were placed in the same aquaria during the feeding period. The latter ones were used as a control for any possible radiotracer recycling from seawater due to radiotracer leaching from the contaminated food or, later on, from depuration from the exposed animals. At the end of the feeding period, each individual (including controls) was whole-body g-counted alive. From then onwards, organisms were regularly radio-analyzed to follow the radiotracer depuration kinetics over $39 \mathrm{~d}$ (shrimp) to 64 d (bivalves). At the end of the depuration period, 3 to 6 individuals of each species were dissected.

\subsubsection{Sediment experiments}

Sediment (3 kg dry wt), collected in Sainte-Marie Bay, New Caledonia, was placed for $7 \mathrm{~d}$ in 3 $\mathrm{L}$ of seawater and daily spiked with $1 \mathrm{kBq} \mathrm{L}^{-1}$ of ${ }^{134} \mathrm{Cs}$, according to the method described by Danis et al. (2003) and adapted by Hédouin et al. (2010). Sediment was then placed in a 70-L aquarium to form a continuous, 2-cm thick layer. Weakly bound radiotracer was allowed leaching overnight under flowing seawater. Bivalves $(n=10-20$ per species $)$ were then placed in the aquarium (flowing natural seawater, flux: $50 \mathrm{~L} \mathrm{~h}^{-1}, \mathrm{~T}^{\circ}: 25 \pm 0.5^{\circ} \mathrm{C}$; salinity: 36 p.s.u.; $\mathrm{pH}$ : $8.0 \pm 0.1$, light/dark cycle: $12 \mathrm{~h} / 12 \mathrm{~h}$ ) for $35 \mathrm{~d}$. All individuals of each species were regularly radio-analyzed during the exposure period. Sediment samples were also regularly collected and $\gamma$-counted to verify that the radiotracer activities remained constant. At the end of the exposure period, some individuals $(\mathrm{n}=3-5$ per species) were collected and dissected for determining ${ }^{134}$ Cs body distribution.

Remaining individuals were transferred for $49 \mathrm{~d}$ into a new aquarium (same conditions as previously described, but with clean - unspiked - sediment) in order to follow the depuration 
kinetics of ${ }^{134} \mathrm{Cs}$. The radioactivity in sediment was regularly checked in order to ensure that no tracer recycling occurred in the sediment. Although no radioactivity was detected in the sediment, the whole sediment was renewed after one week. At the end of the depuration period, some individuals ( $\mathrm{n}=3-5$ per species) were collected and dissected for determining ${ }^{134} \mathrm{Cs}$ body distribution.

\subsubsection{Cs release during ecdysis of the Pacific blue shrimp P. stylirostris}

During both depuration period following seawater and feeding experiments (see 2.3.1 and 2.3.2), few moulting events occurred for the studied shrimp. Associated release of Cs was studied although this was not the scope of the present paper. A description of the collection methodology can be found in Metian et al. (2010) and a brief analysis of the results is available in the Appendix.

\subsection{Data analysis}

Uptake kinetics of $134 \mathrm{Cs}$ were expressed in terms of change in concentration factor $(\mathrm{CF}$, viz. ratio between whole-body activity - $\mathrm{Bq} \mathrm{g}^{-1}$ wet wt - and time-integrated activity of radiotracers in seawater $-\mathrm{Bq} \mathrm{g}^{-1}$ ) over time for the seawater exposure and in terms of change in transfer factors (TF: ratio between the whole-body activity - $\mathrm{Bq} \mathrm{g}^{-1}$ wet wt - and time-integrated activity in the sediment $-\mathrm{Bq} \mathrm{g}^{-1}$ wet $\mathrm{wt}$ ) over time for the sediment exposure.

Kinetics were best described using a simple first-order exponential kinetic model (Eq. (1)):

$\mathrm{CF}_{\mathrm{t}}=\mathrm{CF}_{\mathrm{ss}}\left(1-\mathrm{e}^{-\mathrm{ket}}\right)(1)$

where $\mathrm{CF}_{\mathrm{t}}$ and $\mathrm{CF}_{\mathrm{ss}}$ are the concentration factor at time $\mathrm{t}(\mathrm{d})$ and at steady-state, respectively, and $\mathrm{k}_{\mathrm{e}}$ is the depuration rate constant $\left(\mathrm{d}^{-1}\right)$ (e.g. Whicker and Schultz, 1982). 
Depuration kinetics of ${ }^{134} \mathrm{Cs}$ in seawater, food and sediments experiments were expressed as the change in the percentage of remaining radioactivity (radioactivity at time $t$ divided by the initial radioactivity measured in organisms at the beginning of the decontamination period * 100) over time. The depuration kinetics were best fitted using either a simple-component (Eq. (2)) or twocomponent exponential depuration model (Eq. (3)):

$\mathrm{At}=\mathrm{A}_{0 \mathrm{~s}} \mathrm{e}^{-\mathrm{ket}}(2)$

$\mathrm{At}=\mathrm{A}_{0 \mathrm{~s}} \mathrm{e}^{-\mathrm{kest}}+\mathrm{A}_{01} \mathrm{e}^{-\mathrm{kelt}}(3)$

where ke is the depuration rate constant $\left(\mathrm{d}^{-1}\right), \mathrm{A}_{t}$ and $\mathrm{A}_{0}$ are the remaining activities (\%) at time t (d) and 0, respectively; ' $s$ ' and ' $l$ ' subscripts stand for the short- and long-lived exponential components, respectively. A biological half-life $\left(\mathrm{T}_{\mathrm{b}^{1 / 2 s}}\right.$ and $\left.\mathrm{T}_{\mathrm{b}^{1 / 2}}\right)$ may be calculated from the corresponding depuration rate constant (kes and kel, respectively) according to the relation $\mathrm{T}_{\mathrm{b}^{1 / 2}}$ $=\ln _{2 / \text { ke }}$ (Whicker and Schultz, 1982). Model constants and their statistics were estimated by iterative adjustment of the model using the non linear curve fitting routines in the Statistica ${ }^{\circledR}$ software 7.0. The level of significance for statistical analyses was always set at $\alpha=0.05$.

The relative contribution of each pathway (seawater, food and sediment) was determined using a global bioaccumulation model as detailed in Hédouin et al. (2010). The equation of the model has been modified to integrate each exposure pathway (seawater, food and sediment) as necessary (sediment was not considered for shrimps). The parameters used in the global bioaccumulation model were the biokinetic parameters obtained from our experiments as well as the ingestion rate of each species $\left(\mathrm{g}^{-1} \mathrm{~d}^{-1}\right.$, wet wt basis; from a preliminary set of experiments on bivalves and on shrimp) and the partition coefficients in phytoplankton ( $\mathrm{Kd}_{\mathrm{f}}$; calculated as Concentration Factor after 6 d of exposure e $n=3$-, right before feeding organisms). Partition coefficients in sediment $\left(\mathrm{Kd}_{\mathrm{s}}\right)$ was obtained from the litterature (IAEA, 2004). 


\section{Results}

\subsection{Seawater experiments}

The whole-body uptake kinetics of ${ }^{134} \mathrm{Cs}$ from seawater in the 5 investigated species are depicted in Fig. 1A. They were best described by a first-order exponential model. In both oysters I. isognomum and $M$. regula, ${ }^{134} \mathrm{Cs}$ was taken up in a similar manner, reaching wholebody concentration factors at steady state $\left(\mathrm{CF}_{\mathrm{ss}}\right)$ of $1.29 \pm 0.52$ and $1.21 \pm 0.04$, respectively, after $28 \mathrm{~d}$ (Table 2). ${ }^{134} \mathrm{Cs}$ was accumulated more efficiently in the non-bivalve taxa. Indeed, after $24 \mathrm{~d}$ and $28 \mathrm{~d}$ of exposure, the shrimp P. stylirostris and the alga L. variegata reached whole-body $\mathrm{CF}_{\mathrm{ss}}$ of $8.3 \pm 0.2$ and $15.6 \pm 1.0$, respectively.

The dissections carried out on bivalves during the seawater exposure period allowed determining the uptake kinetics of ${ }^{134} \mathrm{Cs}$ in the whole soft-parts of the 3 species of bivalves (Fig. 2). The latter kinetics were also best described by a first-order exponential model and M. regula displayed a slightly higher concentration factor than I. isognomum and G. pectinatum $\left(\mathrm{CF}_{\mathrm{ss}}\right.$ of $4.62 \pm 0.44,3.74 \pm 0.71$ and $3.26 \pm 0.13$, respectively) although differences were not statistically significant.

The results of the depuration kinetic experiments over 43-62 d after the uptake period are shown in Fig. 1B. The whole-body depuration kinetics were best fitted by a double exponential model in the three bivalves, and were best described by a simple exponential model in the alga and the shrimp. In the case of a double exponential model, the long-term compartment contributed to $38-53 \%$ of the depuration kinetic. In this compartment, Cs was strongly retained ( $22 \mathrm{~d}$ for the clam and tending to infinity for the oysters). At the end of the depuration period, remaining activities in whole soft-parts of the oysters and the clams were $18 \pm 9 \%$ and $19 \pm 14 \%$, respectively (data not shown; the associated model parameters could not be determined accurately for these whole soft-parts depuration). 
The distribution of ${ }^{134} \mathrm{Cs}$ between soft tissues and shells of the organisms at the end of uptake time (28 d) is shown in Table 3 . The major part of the ${ }^{134} \mathrm{Cs}$ activity was localized in the shells in both oysters (80-83\%) whereas in clams the main fraction of ${ }^{134} \mathrm{Cs}$ was present in the softparts, even though shells represented $84 \%$ of the total body weight. Calculated $\mathrm{CF}_{28 \mathrm{~d}}$ in whole soft-parts confirmed this result $\left(\mathrm{CF}_{28 \mathrm{~d}}\right.$ soft-parts: $3.2 \pm 1.1$ vs. $\mathrm{CF}_{28 \mathrm{~d} \text { whole body }} 0.8 \pm 0.3$; Table 4). Substantial concentration capacities of the oyster soft parts were also highlighted by higher $\mathrm{CF}_{28 \mathrm{~d}}$ in the whole soft-parts than for the whole body (Table 4). As for the shrimp, the major part of ${ }^{134} \mathrm{Cs}$ was localized in the abdominal muscle, which contained $87.5 \%$ of whole body activity. At the end of depuration phase, the proportion of Cs associated with whole soft-parts was greater than that observed at the end of the uptake period in both oyster species (increasing from 17 to $20 \%$ at the end of the uptake phase to $60-74 \%$ at the end of the depuration phase). In contrast, the distribution of $134 \mathrm{Cs}$ in the soft tissues of the clams at the end of the depuration phasewas not significantly different than at the end of uptake phase (Table 3).

\subsection{Food experiments}

The whole-body depuration kinetics of ${ }^{134}$ Cs ingested with food were best fitted by a double exponential model in the investigated organisms (oysters, clam and shrimp; Fig. 3 and Table 2). Assimilation efficiencies $\left(\mathrm{A}_{01}\right)$ were variable depending on the species, from 7 to $9 \%$ for the oysters to $39 \%$ and $41 \%$ for the shrimp and the clam. The lowest depuration rate values $\left(\mathrm{k}_{\mathrm{el}}\right)$ were obtained for the clam $\left(0.008 \pm 0.005 \mathrm{~d}^{-1}\right)$. The higher $\mathrm{k}_{\mathrm{el}}$ was observed for the shrimp $\left(0.044 \pm 0.008 \mathrm{~d}^{-1}\right)$. An intermediate situation was observed for the oysters, with $\mathrm{k}_{\mathrm{el}}=0.013 \pm$ $0.003 \mathrm{~d}^{-1}$ for I. isognomum and $0.018 \pm 0.004 \mathrm{~d}^{-1}$ for $M$. regula. The values of $\mathrm{k}_{\mathrm{el}}$ allowed determining $\mathrm{T}_{\mathrm{b}^{1 / 21}}$ ranging between 16 and $89 \mathrm{~d}$ (Table 2). 
At the end of the depuration period, ${ }^{134} \mathrm{Cs}$ was mainly associated with the soft-parts of the bivalves (75-81\% of the total body load; Table 3) except for the oyster I. isognomum for which the largest part of ${ }^{134} \mathrm{Cs}$ was associated with the shell (i.e., 72\%; Table 3). In the shrimp the major part of ${ }^{134} \mathrm{Cs}$ was stored in the muscle $(73 \%)$.

\subsection{Sediment experiments}

The uptake kinetics of the bivalves exposed to radiolabelled sediment during $35 \mathrm{~d}$ were best described by an exponential modelwith a steady state reached within the ten first days of exposure. The values of the ${ }^{134} \mathrm{Cs}$ transfer factor at steady state $\left(\mathrm{TF}_{\mathrm{ss}}\right)$ were low $(<0.1)$ for all species examined (Fig. 4A, Table 2).

The depuration kinetics were best described by a double exponential model. The proportion of ${ }^{134} \mathrm{Cs}$ associated with the long-lived component was higher than in the depuration kinetics observed after the seawater and dietary exposures. The biological half-life of ${ }^{134} \mathrm{Cs}$ depurated according to this long-lived component ranged between 36 and 58 d. Both oysters displayed similar behavior and retained $62-63 \%$ of ${ }^{134} \mathrm{Cs}$ from sediment vs. $79 \%$ for the clam (Fig. 4B, Table 2).

The body distribution of ${ }^{134} \mathrm{Cs}$ at the end of the exposure period ( $\left.35 \mathrm{~d}\right)$ is shown in Table 3 . The major part of the ${ }^{134}$ Cs activity was associated with the shell for both oysters (>98\%) as well as for the clam (78\%; Table 3). The fraction of ${ }^{134} \mathrm{Cs}$ associated with the soft-parts of the bivalves represented only $<2 \%-22 \%$, and $\mathrm{TF}_{30 \mathrm{~d}}$ lower than whole-body were calculated in the soft-parts (Table 4).

At the end of the depuration period, tissue distribution of ${ }^{134} \mathrm{Cs}$ was similar with ${ }^{134} \mathrm{Cs}$ mainly located in the shells of all bivalves (>94\%; Table 3). 


\subsection{Bioaccumulation model}

The relative contribution of each exposure pathway to the global bioaccumulation of ${ }^{134} \mathrm{Cs}$ in the bivalves and the shrimp was calculated using the kinetic parameters determined in the different experiments (see paragraph 2.4. and Table 2) and other parameters such as the ${ }^{134} \mathrm{Cs}$ $\mathrm{K}_{\mathrm{df}}$ in phytoplankton (8178 for I. galbana; present study) and mussel (100;Wang et al., 2000), $\mathrm{K}_{\mathrm{ds}}$ in sediment (4000; IAEA, 2004) and the ingestion rates determined in bivalves and shrimp (IR $=0.0046-0.0149 \mathrm{~g} \mathrm{~g}^{-1} \mathrm{~d}^{-1}$ and $0.3472 \mathrm{~g} \mathrm{~g}^{-1} \mathrm{~d}^{-1}$ respectively; present study). Results of the computations indicate that the food pathway was the major contributor (56-83\%) to the global bioaccumulation of ${ }^{134} \mathrm{Cs}$ in the different taxa whereas seawater and sediment contributed for $<1-31 \%$ and 6-24\%, respectively (Fig. 5).

\section{Discussion}

There is currently a lack of knowledge about the bioacumulation of ${ }^{134} \mathrm{Cs}$ in tropical marine taxa and thereby on the relative importance of the different exposure pathways for these organisms. Based on the fact that temperature influences positively the uptake of Cs in marine organisms, some authors have speculated that tropical marine species such as bivalves may have higher Cs accumulation capacity than similar species from temperate regions (Ke et al., 2000). The present study provides first answers to this assumption by characterizing Cs accumulation in different species from New Caledonia (South Pacific) exposed via different pathways (seawater, food and sediment) and by comparing results obtained with published data on Cs accumulation in different temperate species (see Fig. 6).

In this study, whole-body CFs of $134 \mathrm{Cs}$ were generally low ( $<1.3$ for bivalves) but in accordance with the values reported in other studies, which ranged between 0.8 and 7 , with maximal values for the clam Macridiscus melanaegis (Ueda et al., 1978). Our results indicate that tropical bivalves did not accumulate ${ }^{134}$ Cs more than species from temperate regions (Fig. 
6) as what was speculated in mussels (Ke et al., 2000) or in freshwater fish (Twining et al., 1996).

The similarity of concentration capacities between tropical and temperate species is also true for the studied alga and shrimp. Indeed, the CF obtained in P. stylirostris (8.26) is relatively low compared to CFs from temperate decapod crustaceans (Fig. 6). For example, Sezer et al. (2014) observed CF of 15 after $30 \mathrm{~d}$ of exposure in the Baltic prawn Palaemon adspersus.

In the present study kinetics parameters were mainly obtained from whole-body kinetics analyses, thus including the shell compartment. The role of the shell was somehow highlighted during our experiments and it can explain some of the differences observed among species. For example, during the exposure to ${ }^{134} \mathrm{Cs}$ by radiolabelled sediment, whole body TFs were strongly different between oysters and clams (factor 4 higher for oysters) whereas TFs in whole softparts did not differ to such a high extent (Table 4).

Compared to whole-body weight, shell weigth in oysters and clams greatly differ, as well as the shell anatomy, structure and composition. In addition, shell surface/volume ratio is much higher in oysters (flattened shape) than in clams (rounded shape). All these shell characteristics can influence whole-body bioaccumulation kinetics, as shown in the results section of this study (e.g. body distribution of $\mathrm{Cs}$ or CFs and TFs in whole-body individuals vs. their body compartments). In particular our results showed that shells of the oysters are much more Csreactive than those of the clams for which the soft-parts are the main accumulator of Cs.

The study also showed that the distribution of ${ }^{134} \mathrm{Cs}$ in bivalves and shrimp was pathway- and species-dependent. In most cases, ${ }^{134} \mathrm{Cs}$ ingested from food was associated with internal tissues.Wang et al. (2000) have already demonstrated that more than $99.5 \%$ of ${ }^{134} \mathrm{Cs}$ was concentrated in the soft-parts of the scavenging gastropod Babylonia formosae habei after food exposure. Conversely, in most cases, when organisms were exposed via seawater, Cs was mainly associated with the shells. This result is not surprising as adsorption processes on 
external surfaces are logically dominant when organisms are exposed through ambient water, whereas absorption processes through internal surfaces are dominant when exposed via the food (Carvalho and Fowler, 1993; Guary and Fowler, 1990).

The determination of the predominant uptake pathway(s) of ${ }^{134} \mathrm{Cs}$ provides important information. Some authors have reported that food is the major route for Cs uptake in taxa such as cephalopods (Bustamante et al., 2006), teleosts and elasmobranchs (Hewett and Jefferies, 1978; Pentreath and Jefferies, 1971). Sediments can also act as a significant source of contaminants to filter-feeders and burrowing organisms (e.g., Fisher and Reinfelder, 1995; Luoma,1995). For instance, particulate matter can represents $13 \%$ of the source of accumulated Cs in the green mussel Perna veridis (Wang et al., 2000). However, most of the previous studies assessed relative importance of uptake pathways by comparing kinetic parameters or $\mathrm{CF}$ and TF. Actually such simple comparison is not that informative. Indeed, TF from sediment are generally much lower than $\mathrm{CF}$ from sea water, but the radionuclide concentration in sediment is generally much higher than that in seawater; bioaccumulated quantities depend on both parameters. The bioaccumulation model developed by Thomann (1981) and Thomann et al. (1995) allows the determination of relative contributions (Landrum et al., 1992). Our study showed that food was the main source of Cs for the 3 bivalve species studied as well as for the Pacific blue shrimp. The proportion of dietary contribution is not clearly dependent of the AE factor. Indeed, although both oyster species have similar and relatively low AE (7-9\%), the dietary contribution varied largely (56-83\%). But the contribution of food was positively related to their ingestion rate (IR): I. isognomum had a lower IR than M. regula $\left(0.0046 \mathrm{~g} \mathrm{~g}^{-1} \mathrm{~d}^{-1} \mathrm{vs}\right.$. $0.0149 \mathrm{~g} \mathrm{~g} \mathrm{~g}^{-1} \mathrm{~d}^{-1}$, respectively) and a lower contribution of food (56\% vs. $\left.83 \%\right)$. Similarly to bivalves, this relation also exists for P. stylirostris (high IR - $0.0434 \mathrm{~g} \mathrm{~g}^{-1} \mathrm{~d}^{-1}$ - and a relatively high proportion of the Cs coming from food e $78 \%$-). Altough there are not directly comparable due to the different food tested (mussels vs. phytoplankton). 


\section{Conclusion}

The present study provides new information about Cs accumulation in different tropical marine taxa. Results indicate that the selected tropical species accumulate globally Cs similarly than species from temperate regions but absorption efficiency seems to be greater in the tropical species. Nonetheless, there are large interspecific differences regarding the physiological parameters driving the accumulation of the radionuclide via the three different pathways tested (seawater, food and sediments). The use of a global bioaccumulation model based on wholebody biokinetic parameters showed that food was the predominant uptake pathway for ${ }^{134} \mathrm{Cs}$ bioaccumulation in the 3 bivalve species and the Pacific blue shrimp.

\section{Acknowledgments}

This work was supported by the IAEA. The IAEA is grateful for the support provided to its Environment Laboratories by the Government of the Principality of Monaco. The authors thank the Ifremer Station of St Vincent, New Caledonia for providing the shrimp, the IRD Center of Noumea, NewCaledonia for providing the other tested organisms and E. Girard for her work on the Cs database. LH was beneficiary of a PhD grant (CIFRE, France) supported by the GoroNickel Company, New Caledonia. MW is an Honorary Senior Research Associate of the National Fund for Scientific Research (NFSR, Belgium). MM is Nippon foundation Nereus program Alumni.

\section{Appendix. Supplementary data}

Supplementary data related to this article can be found at http://dx.doi.org/10.1016/j.jenvrad.2015.11.012. 


\section{References}

Bailly du Bois, P., Laguionie, P., Boust, D., Korsakissok, I., Didier, D., Fiévet, B., 2012. Estimation of marine source-term following Fukushima Dai-ichi accident. J. Environ. Radioact.114, 2-9.

Børretzen, P., Salbu, B., 2009. Bioavailability of sediment-associated and low molecular-mass species of radionuclides/trace metals to the mussel Mytilus edulis. J. Environ. Radioact. 100, 333-341.

Bryan, G.W., 1963. The accumulation of radioactive caesium by marine invertebrates. J. Mar. Biol. Assoc. U. K. 43, 519-539.

Bryan, G.W.,Ward, E., 1962. Potassium metabolism and the accumulation of ${ }^{137}$ Cs by decapod Crustacea. J. Mar. Biol. Assoc. U. K. 42, 199-241.

Buesseler, K.O., 2012. Fishing for answers off fukushima. Science 338, 480e482.

Buesseler, K.O., Jayne, S.R., Fisher, N.S., Rypina, I.I., Baumann, H., Baumann, Z., Breier, C.F., Douglass, E.M., George, J., Macdonald, A.M., Miyamoto, H., Nishikawa, J., Pike, S.M., Yoshida, S., 2012. Fukushima-derived radionuclides in the ocean and biota off Japan. Proc. Nat. Acad. Sci. 109, 5984-5988.

Bustamante, P., Teyssié, J.-L., Fowler, S.W., Warnau, M., 2006. Assessment of the exposure pathway in the uptake and distribution of americium and cesium in cuttlefish (Sepia officinalis) at different stages of its life cycle. J. Exp. Mar. Biol. Ecol. 331, 198-207.

Carlson, L., Erlandsson, B., 1991. Effects of salinity on the uptake of radionuclides by Fucus vesiculosus L. J. Environ. Radioact. 13, 309-322.

Carvalho, F.P., Fowler, S.W., 1993. An experimental study on the bioaccumulation and turnover of $\mathrm{Po}^{210}$ and $\mathrm{Pb}^{210}$ in marine shrimp. Mar. Ecol. Prog. Ser. 102, 125-133.

Chino, M., Nakayama, H., Nagai, H., Terada, H., Katata, G., Yamazawa, H., 2011.Preliminary estimation of release amounts of ${ }^{131} \mathrm{I}$ and ${ }^{137} \mathrm{Cs}$ accidentally discharged from the Fukushima Daiichi nuclear power plant into the atmosphere. J. Nucl. Sci. Technol. 48, $1129-1134$.

Cranmore, G., Harrison, F.L., 1975. Loss of ${ }^{137} \mathrm{Cs}$ and ${ }^{60} \mathrm{Co}$ from the oyster Crassostrea gigas. Health Physics. 28(4), pp. 319-333.

Danis, B., Cotret, O., Teyssié, J.L., Fowler, S.W., Bustamante, P., Warnau, M., 2003. Delineation of PCB uptake pathways in a benthic sea star using a radiolabelled congener. Mar. Ecol. Prog. Ser. 253, 155-163. 
Evans, S., 1984. Uptake and loss of ${ }^{134} \mathrm{Cs}$ and ${ }^{60} \mathrm{Co}$ by the Baltic bivalve Macoma baltica in a laboratory microcosmos. J. Environ. Radioact. 1, 133-150.

Fisher, N.S., Reinfelder, J.R., 1995. The trophic transfer of metals in marine systems. In: Tessier, A., Turner, D.R. (Eds.), Metal Speciation and Bioavailability in Aquatic Systems. United Kingdom, Chichester, pp. 363-406.

Friedlander, B.R., Gochfeld, M., Burger, J., Powers, C.W., 2005. Radionuclides in the marine environment: a CRESP science review. In: Consortium for Risk Evaluation with Stakeholder Participation, Nashville, TN, p. 95.

Guary, J.C., Fowler, S.W., 1990. Experimental study of the transfer of transuranium nuclides in marine decapod crustaceans. Mar. Ecol. Prog. Ser. 60, 253-270.

Güngör, N., Tuğrul, B., Topcuoğlu, S., Güngör, E., 2001.Experimental studies on the biokinetics of ${ }^{134} \mathrm{Cs}$ and ${ }^{241} \mathrm{Am}$ in mussels (Mytilus galloprovincialis). Environ. Int. 27, 259-264.

Gutknecht, J., 1965. Uptake and retention of ${ }^{137} \mathrm{Cs}$ and ${ }^{65} \mathrm{Zn}$ by seaweeds I. Limnol. Oceanogr. 10, 58-66.

Hamada, N., Ogino, H., 2012. Food safety regulations: what we learned from the Fukushima nuclear accident. J. Environ. Radioact. 111, 83-99.

Hattink, J., Celis, N., De Boeck, G., Krijger, G.C., Blust, R., 2009. Accumulation of ${ }^{137}$ Cs in the European sea bass Dicentrarchus labrax (L.) in a salinity gradient: importance of uptake via gills, diet and ingested water. Radioprotection 44, 665-670.

Hédouin, L., Metian, M., Teyssié, J.-L., Fowler, S.W., Fichez, R., Warnau, M., 2006. Allometric relationships in the bioconcentration of heavy metals by the edible tropical clam Gafrarium tumidum. Sci. Total Environ. 366, 154-163.

Hédouin, L., Metian, M., Teyssié, J.-L., Fichez, R., Warnau, M., 2010. Delineation of heavy metal contamination pathways (seawater, food and sediment) in tropical oysters from New Caledonia using radiotracer techniques. Mar. Pollut. Bull. 61, 542-553.

Hewett, C.J., Jefferies, D.F., 1978. The accumulation of radioactive caesium from food by the plaice (Pleuronectes platessa) and the brown trout (Salmo trutta). J. Fish Biol. 13, 143153.

International Atomic Energy Agency (IAEA), 1975. Design of Radiotracer Experiments in Marine Biological Systems. Technical Reports Series no.167. IAEA, Vienna, Austria.

International Atomic Energy Agency (IAEA), 2004. Sediments Distribution Coefficients and Concentration Factors for Biota in the Marine Environment. Technical Reports Series no.422. IAEA, Vienna, Austria, p. 18. 
Ito, T., Povinec, P.P., Togawa, O., Hirose, K., 2003. Temporal and spatial variations of anthropogenic radionuclides in Japan sea waters. Deep Sea Res. Part II Top. Stud. Oceanogr. 50, 2701-2711.

Kalayc1, G., Belivermiş, M., Kılıç, Ö.,Topcuoğlu, S., Çotuk, Y., 2013. Investigation of radiocesium biokinetics in Manila clam (Ruditapes philippinarum). J. Radioanal. Nucl. Chem. 295, 239-244.

Kawai, H., Kitamura, A., Mimura, M., Mimura, T., Tahara, T., Aida, D., Sato, K., Sasaki, H., 2013. Radioactive cesium accumulation in seaweeds by the Fukushima 1 nuclear power plant accidentdtwo years' monitoring at Iwaki and its vicinity. J. Plant Res. 127, 23-42.

Ke, C., Yu, K.N., Lam, P.K.S., Wang, W.-X., 2000. Uptake and depuration of cesium in the green mussel Perna viridis. Mar. Biol. 137, 567-575.

Landrum, P.F., Lydy, M.J., Lee, H., 1992. Toxicokinetics in aquatic systems: Model comparisons and use in hazard assessment. Environ. Toxicol. Chem. 11, 1709-1725.

Luoma, S.N., 1995. Prediction of metal toxicity in nature from bioassays: limitations and research needs. In: Tessier, A., Turner, D.R. (Eds.), Metal Speciation and Bioavailability in Aquatic Systems. United Kingdom, Chichester, pp. 609-660.

Mathews, T., Fisher, N.S., 2008. Trophic transfer of seven trace metals in a four-step marine food chain. Mar. Ecol. Prog. Ser. 367, 23-33.

Mathews, T., Fisher, N.S., Jeffree, R.A., Teyssié, J.-L., 2008. Assimilation and retention of metals in teleost and elasmobranch fishes following dietary exposure. Mar. Ecol. Prog. Ser. 360, 1-12.

Metian, M., Hédouin, L., Eltayeb, M.M., Lacoue-Labarthe, T., Teyssié, J.-L., Mugnier, C., Bustamante, P., Warnau, M., 2010. Metal and metalloid bioaccumulation in the Pacific blue shrimp Litopenaeus stylirostris (Stimpson) from New Caledonia: laboratory and field studies. Mar. Pollut. Bull. 61, 576-584.

Metian, M., Warnau, M., Cosson, R.P., Oberh€ansli, F., Bustamante, P., 2008. Bioaccumulation and detoxification processes of $\mathrm{Hg}$ in the king scallop Pecten maximus: field and laboratory investigations. Aquat. Toxicol. 90, 204-213.

Metian, M., Warnau, M., Hédouin, L., Bustamante, P., 2009. Bioaccumulation of essential metals (Co, $\mathrm{Mn}$ and $\mathrm{Zn}$ ) in the king scallop Pecten maximus: seawater, food and sediment exposures. Mar. Biol. 156, 2063-2075.

Metian, M., Warnau, M., Teyssié, J.-L., Bustamante, P., 2011. Characterization of ${ }^{241} \mathrm{Am}$ and ${ }^{134} \mathrm{Cs}$ bioaccumulation in the king scallop Pecten maximus: investigation via three exposure pathways. J. Environ. Radioact. 102, 543-550. 
Mittelstaedt, E., Osvath, I., Povinec, P.P., Togawa, O., Scott, E.M., 1999. Transport of radionuclides from the Mururoa and Fangataufa atolls through the marine environment. Sci. Total Environ. 237e238, 301-309.

Morgan, F., 1964. The uptake of radioactivity by fish and shellfish I: ${ }^{134} \mathrm{Cs}$ by whole animals. J. Mar. Biol. Assoc. U. K. 44, 259-271.

Nolan, C., Dahlgaard, H., Nolan, C., Dahlgaard, H., 1991. Accumulation of metal radiotracers by Mytilusedulis. Mar. Ecol. Prog. Ser. 70, 165-174.

Norfaizal, M., Nita Salina, A.B., Nur Hidaya Dmuliany, M.S., Zal U'yun, W.M., Zaharudin, A., 2010. Experimental Studies on the Biokinetics of ${ }^{134} \mathrm{Cs}$ and ${ }^{109} \mathrm{Cd}$ in the Blood Cockle Anadara Granosa. Waste Technology and Environmental Division Malaysian Nuclear Agency, Kajang, Malaysia.

Pentreath, R.J., Jefferies, D.F., 1971. The Uptake of Radionuclides by I-Group Plaice (Pleuronectes platessa) off the Cumberland Coast, Irish Sea. J. Mar. Biol. Assoc. U. K. 51, 963-976.

Pouil, S., Bustamante, P., Warnau, M., Oberh€ansli, F., Teyssié, J.-L., Metian, M., 2015. Delineation of 134Cs uptake pathways (seawater and food) in the variegated scallop Mimachlamys varia. J. Environ. Radioact. 148, 74-79.

Qureshi, R.M., Mashiatullah, A., Yaqoob, N., Akhtar, P., Chaghtai, F., Jabbar, A., Warnau, M., 2007. Bioaccumulation of ${ }^{137} \mathrm{Cs}, \mathrm{Zn}$ and $\mathrm{Cr}[\mathrm{VI}]$ in the green mussel Perna viridis: influence of salinity and temperature. Environ. Bioindic. 2, 245-252.

Rowan, D.J., Rasmussen, J.B., 1994. Bioaccumulation of radiocesium by fish: the influence of physicochemical factors and trophic structure. Can. J. Fish. Aquat. Sci. 51, 2388-2410.

Rodriguez y Baena, A.M., Miquel, J.C., Masqué, P., Povinec, P.P., La Rosa, J., 2006. A single vs. double spike approach to improve the accuracy of ${ }^{234} \mathrm{Th}$ measurements in smallvolume seawater samples. Mar. Chem. 100, 269-281.

Sezer, N., Belivermis, , M., Kılıç, O., Topcuoğlu, S., Çotuk, Y., 2014. Biokinetics of radiocesium in shrimp (Palaemon adspersus): seawater and food exposures. J. Environ. Radioact. 132, 15-20.

Suzuki, Y., Nakahara, M., Nakamura, R., 1978. Accumulation of ${ }^{137}$ Cs by useful mollusca. Nippon. Suisan Gakk 44, 325-329.

Thomann, R.V., 1981. Equilibrium model of fate of microcontaminants in diverse aquatic food chains. Can. J. Fish. Aquat. Sci. 38, 280-296. 
Thomann, R.V., Mahony, J.D., Mueller, R., 1995. Steady-state model of biota sediment accumulation factor for metals in two marine bivalves. Environ. Toxicol. Chem. 14, 1989-1998.

Topcuoğlu, S., 2001. Bioaccumulation of ${ }^{137} \mathrm{Cs}$ by biota in different aquatic environments. Chemosphere 44, 691-695.

Twining, J.R., Ferris, J.M., Markich, S.J., 1996. Bioaccumulation of ${ }^{137} \mathrm{Cs}$ and ${ }^{85} \mathrm{Sr}$ by an Australian sub-tropical freshwater teleost (Bidyanus bidyanus). Sci. Total Environ. 192, 245-257.

Ueda, T., Nakamura, R., Suzuki, Y., 1978. Comparison of influences of sediments and sea water on accumulation of radionuclides by marine organisms.

Wang, W.-X., Ke, C., Yu, K.N., Lam, P.K.S., 2000. Modeling radiocesium bioaccumulation in a marine food chain. Mar. Ecol. Prog. Ser. 208, 41-50.

Warnau, M., Fowler, S.W., Teyssié, J.-L., 1996a. Biokinetics of selected heavy metals and radionuclides in two marine macrophytes: the seagrass Posidonia oceanica and the alga Caulerpa taxifolia. Mar. Environ. Res. 41, 343-362.

Warnau, M., Teyssié, J.-L., Fowler, S.W., 1996b. Biokinetics of selected heavy metals and radionuclides in the common Mediterranean echinoid Paracentrotus lividus: sea water and food exposures. Mar. Ecol. Prog. Ser. 141, 83-94.

Whicker, F.W., Schultz, V., 1982. Radioecology: Nuclear Energy and the Environment. CRC Press Inc., Boca Raton, Florida.

Yu, P.K.N., Lam, P.K.S., Ng, B.K.P., Li, A.M.Y., 2000. Biokinetics of cesium in Perna viridis. Environ. Toxicol. Chem. 19, 271-275.

Zhao, X., Wang, W.-X., Yu, P.K.N., Lam, P.K.S., 2001. Biomagnification of radiocesium in a marine piscivorous fish. Mar. Ecol. Prog. Ser. 222, 227-237. 

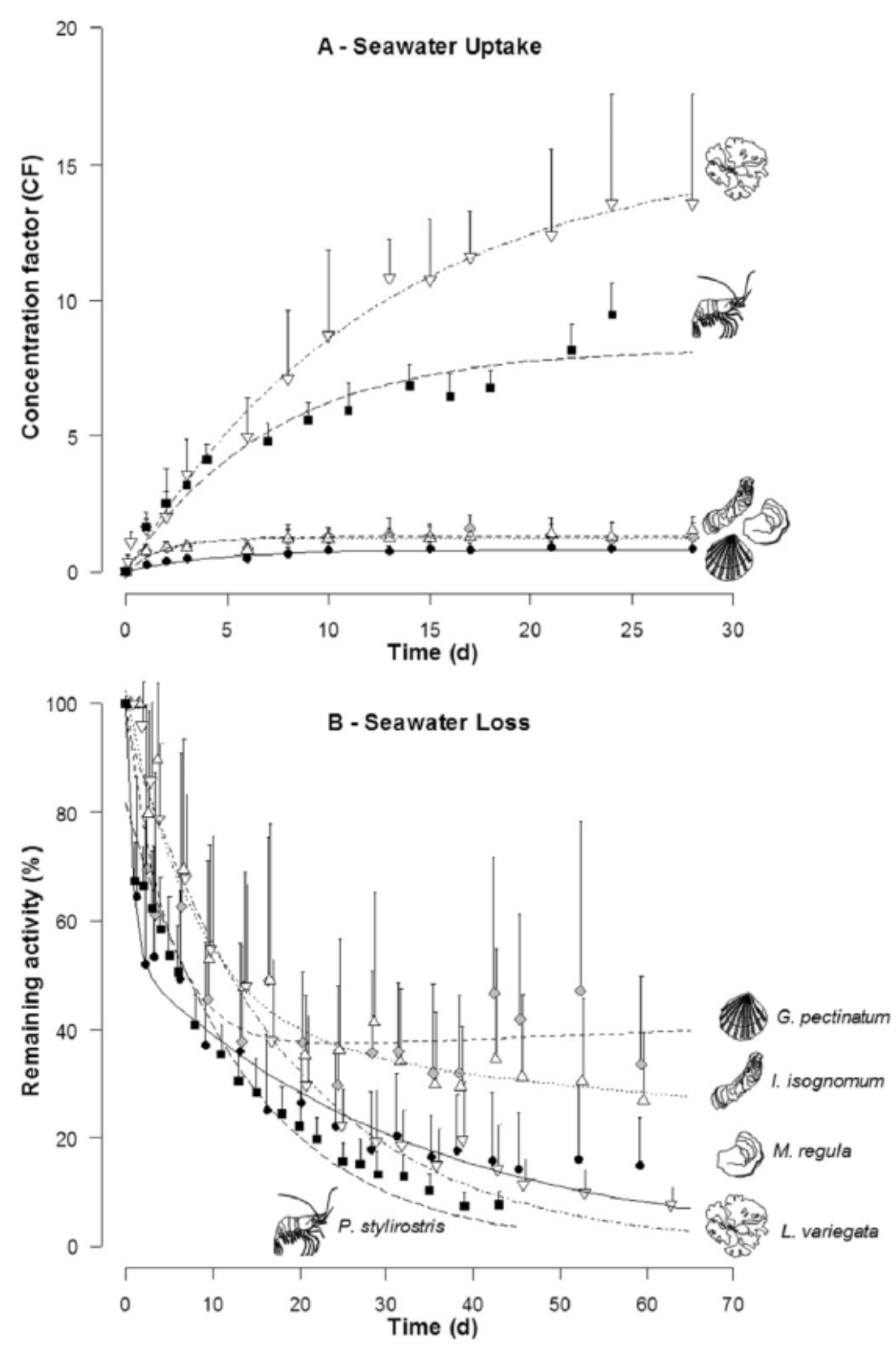

Figure 1. Uptake kinetics (A) of Cs in three bivalve's species (G. pectinatum, I. isognomum and M. regula), one species of shrimp (P. stylirostris) and one alga (L. variegata) for $24-28 \mathrm{~d}$ to dissolved radiotracers $(\mathrm{n}=10-22)$ and their following depuration kinetics $(B)$ when thereafter maintained for 43-62 $d$ in clean seawater $(n=7-15)$. All values are mean + SD and equations of kinetic models are described in Table 2. 


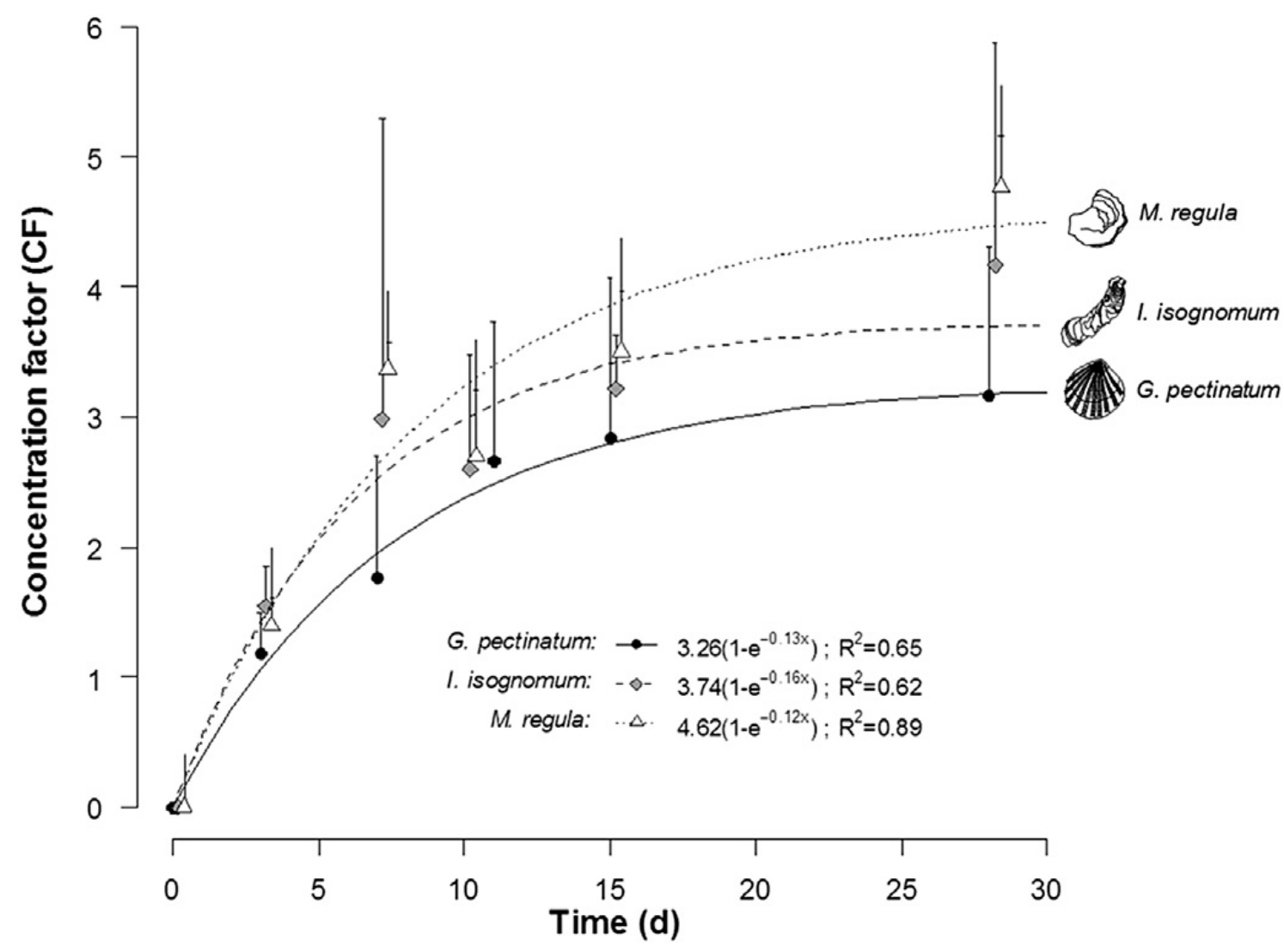

Figure 2. Whole soft-parts Concentration Factors $(C F$, mean $\pm S D, n=3-5)$ of ${ }^{134} \mathrm{Cs}$ in three bivalve species (G. pectinatum, I. isognomum and M. regula) during seawater experiment (28 d-exposure). 


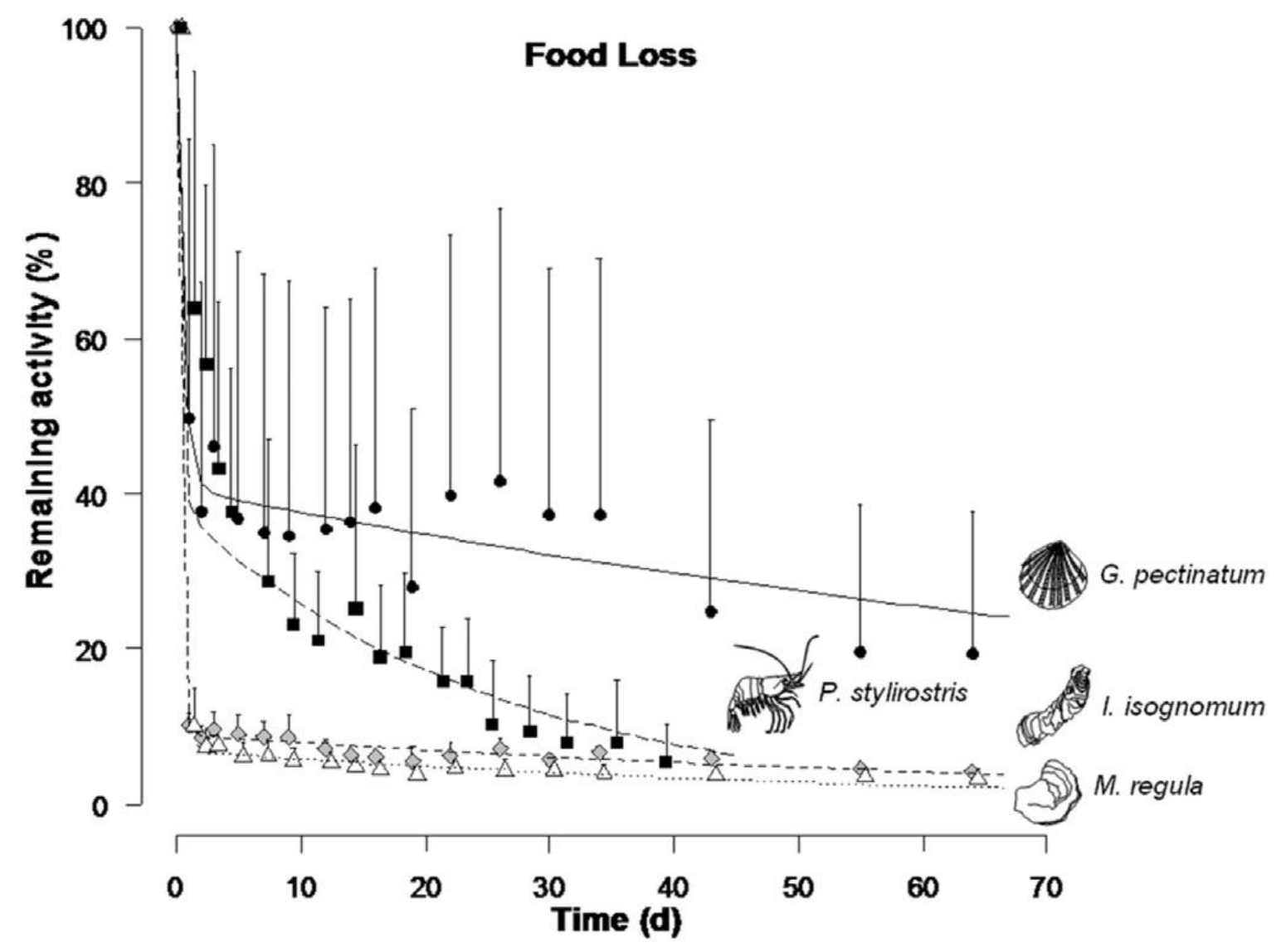

Fig. 3. Depuration kinetics of Cs in three bivalve's species (G. pectinatum, I. isognomum and M. regula) and one species of shrimp (P. stylirostris) respectively after a $2 \mathrm{~h}$ feeding on radiolabelled I. galbana followed by $64 \mathrm{~d}$ of depuration $(\mathrm{n}=6-12)$ and a $3 \mathrm{~h}$ feeding on radiolabelled M. edulis followed by $43 \mathrm{~d}$ of depuration $(\mathrm{n}=20)$. All values are mean $+\mathrm{SD}$ and equations of kinetic model are described in Table 2. 

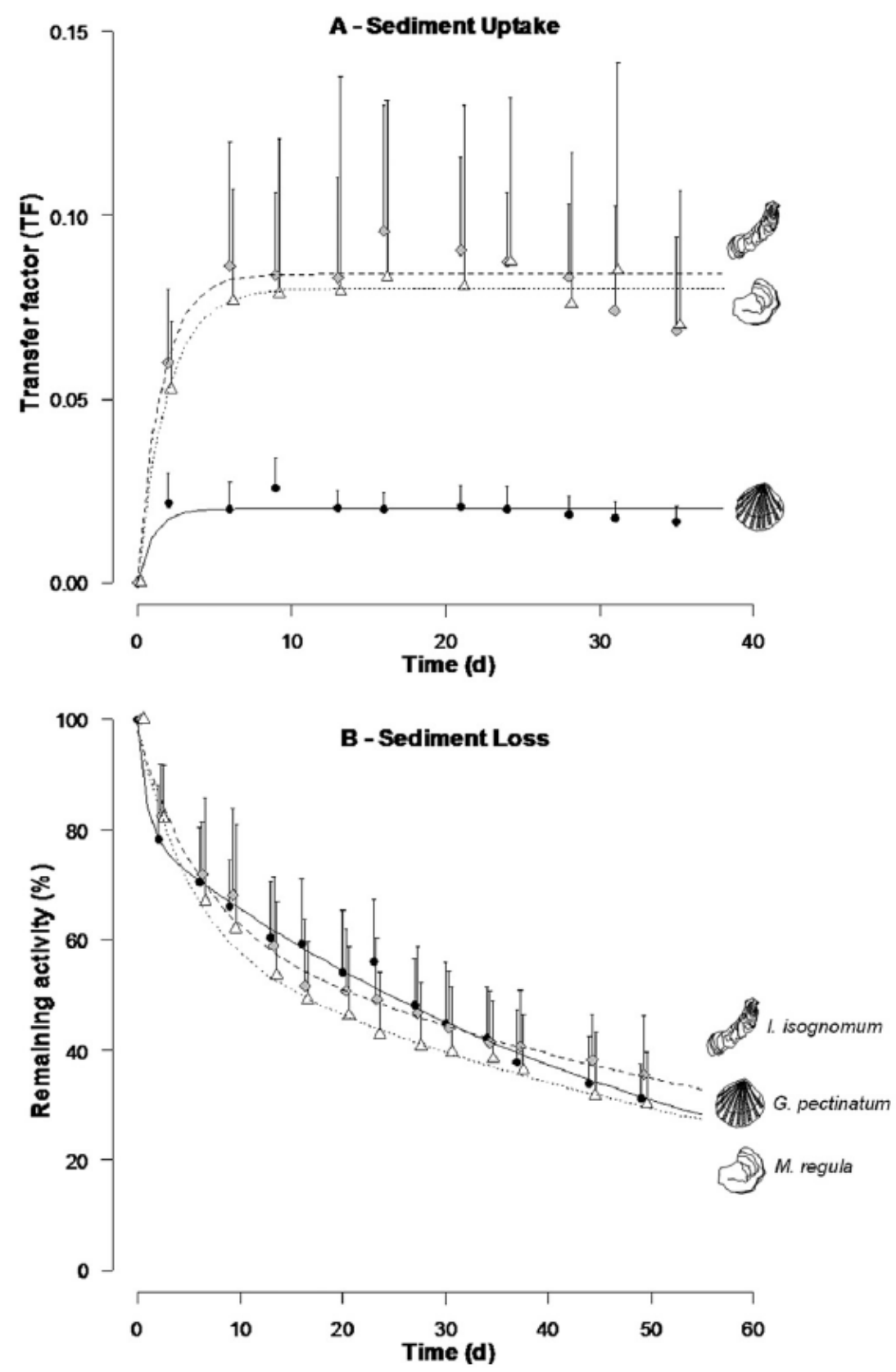

Figure 4. Uptake kinetics (A) of Cs in three bivalve's species (G. pectinatum, I. isognomum and M. regula $)$ exposed for $35 \mathrm{~d}$ to the radiolabelled sediments $(\mathrm{n}=10-20)$ and their following depuration kinetics (B) when thereafter maintained for $49 \mathrm{~d}$ in clean sediment and seawater (n $=7-15)$. All values are mean $+\mathrm{SD}$ and equations of kinetic model are described in Table 2 . 


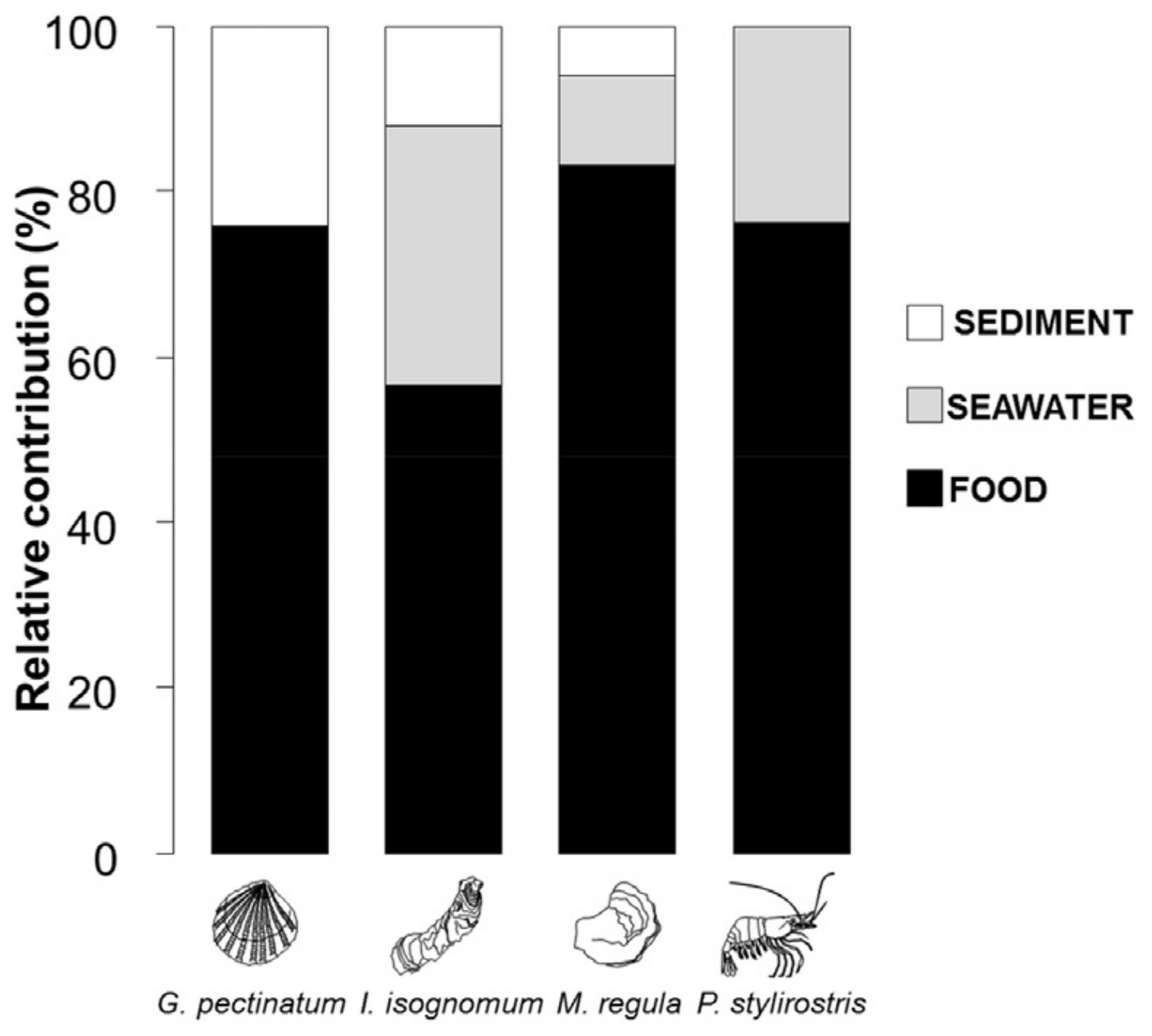

Figure 5. Relative contributions (\%) of the uptake pathways (seawater, food and sediment) to the total bioaccumulation of ${ }^{134} \mathrm{Cs}$ in three bivalve's species (G. pectinatum, I. isognomum and M. regula), one species of shrimp (P. stylirostris) and one species of algae (L. variegata). 


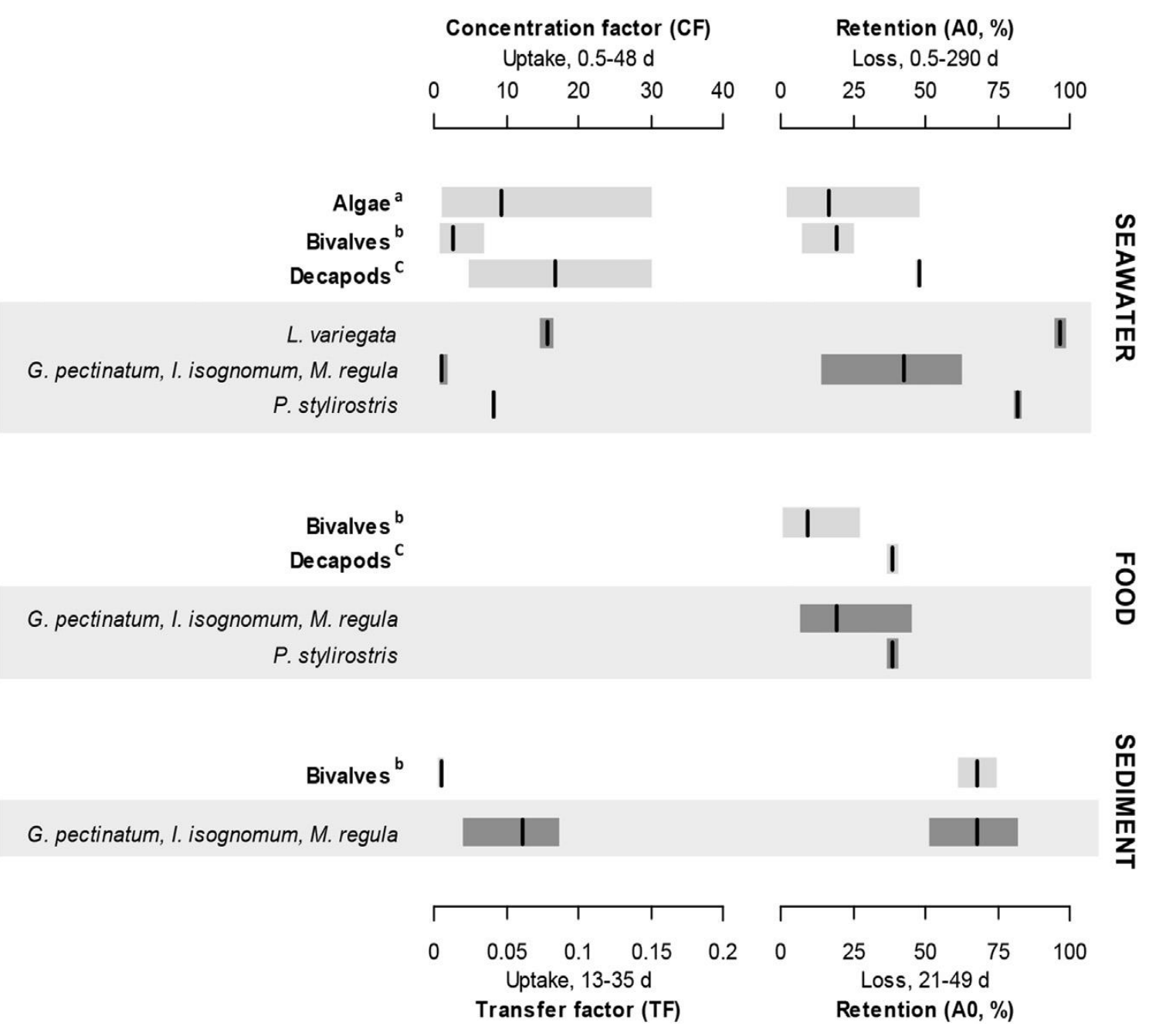

Figure 6. Comparison of kinetic parameters: concentration and transfer factors (TF and CF) and percentages of retention $\left(\mathrm{A}_{0}\right)$ obtained for $\mathrm{Cs}$ from in different taxa in experimental conditions. For each study, three values were considered: the mean and the mean $\pm \mathrm{SD}$ obtained for $\mathrm{CF}$ and/or $\mathrm{A}_{0}$. When the values were not directly available, a graphical estimate was performed from uptake and depuration kinetics. Bars are ranges of values. Light gray and dark gray bars represent respectively values from literature and values of this study. Black vertical lines indicate means calculated from all the considerate values. ${ }^{a}$ (Gutknecht, 1965; Topcuoğlu, 2001; Ueda et al., 1978; Warnau et al., 1996). ' (Børretzen and Salbu, 2009; Bryan, 1963; Cranmore and Harrison, 1975; Evans, 1984; Güngor et al., 2001; IAEA, 1975; Kalayc1 et al., 2013; Metian et al., 2011; Morgan, 1964; Nolan and Dahlgaard, 1991; Norfaizal et al., 2010; Pouil et al., 2015; Qureshi et al., 2007; Suzuki et al., 1978; Ueda et al., 1978; Wang et al., 2000; Yu et al., 2000). '(Bryan and Ward, 1962; Morgan, 1964; Sezer et al., 2014; Topcuoğlu, 2001; Warnau et al., unpublished data). 
Table 1. Experimental conditions used for the different independent experiments. The conditions of exposure were similar the one from to acclimation period $\left(\mathrm{T}^{\circ}: 25 \pm 0.5^{\circ} \mathrm{C}\right.$; salinity: 36 p.s.u.; pH: $8.0 \pm 0.1$; light/dark cycle: 12 h/12 h).

\begin{tabular}{|c|c|c|c|c|c|c|}
\hline \multirow[t]{2}{*}{ Species } & \multirow[t]{2}{*}{ Experimental conditions } & \multicolumn{2}{|l|}{ Seawater } & \multirow{2}{*}{$\frac{\text { Food }}{\text { Loss }}$} & \multicolumn{2}{|c|}{ Sediment } \\
\hline & & Uptake & Loss & & Uptake & Loss \\
\hline \multirow[t]{4}{*}{ G. pectinatum } & Number of individuals & 221 & 15 & 12 & 20 & 15 \\
\hline & Size (Range, mm) & $35-40$ & $35-40$ & $35-40$ & $35-40$ & $35-40$ \\
\hline & Time $(\mathrm{d})$ & 28 & 59 & 64 & 35 & 49 \\
\hline & Nominal activity ( $\mathrm{Bq} \mathrm{g}^{-1}$ or $\mathrm{Bq} \mathrm{L}^{-1}$ ) & 1.6 & - & - & 1 & - \\
\hline \multirow[t]{4}{*}{ I. isognomum } & Number of individuals & 10 & 7 & 6 & 10 & 7 \\
\hline & Size (Range, $\mathrm{mm}$ ) & $70-95$ & $70-95$ & $70-95$ & $70-95$ & $70-95$ \\
\hline & Time $(\mathrm{d})$ & 28 & 59 & 64 & 35 & 49 \\
\hline & Nominal activity ( $\mathrm{Bq} \mathrm{g} \mathrm{g}^{-1}$ or $\left.\mathrm{Bq} \mathrm{L}^{-1}\right)$ & 1.6 & - & - & 1 & - \\
\hline \multirow[t]{4}{*}{ M. regula } & Number of individuals & 10 & 7 & 6 & 10 & 7 \\
\hline & Size (Range, mm) & $70-95$ & $70-95$ & $70-95$ & $70-95$ & $70-95$ \\
\hline & Time $(\mathrm{d})$ & 28 & 59 & 64 & 35 & 49 \\
\hline & Nominal activity ( $\mathrm{Bq} \mathrm{g} \mathrm{g}^{-1}$ or $\left.\mathrm{Bq} \mathrm{L}^{-1}\right)$ & 1.6 & - & - & 1 & - \\
\hline \multirow[t]{4}{*}{ P. stylirostris } & Number of individuals & 20 & 20 & 20 & - & - \\
\hline & Wet weight $($ Mean $\pm S D, g)$ & $7.2 \pm 1.1$ & $7.2 \pm 1.1$ & $7.2 \pm 1.1$ & - & - \\
\hline & Time $(\mathrm{d})$ & 24 & 43 & 39 & - & - \\
\hline & Nominal activity ( $\mathrm{Bq} \mathrm{g} \mathrm{g}^{-1}$ or $\mathrm{Bq} \mathrm{L}^{-1}$ ) & 1 & - & - & - & - \\
\hline \multirow[t]{4}{*}{ L. variegata } & Number of individuals & 12 & 12 & - & - & - \\
\hline & Wet weight $($ Mean $\pm S D, g)$ & $1.7 \pm 0.7$ & $1.7 \pm 0.7$ & - & - & - \\
\hline & Time (d) & 28 & 62 & - & - & - \\
\hline & Nominal activity ( $\mathrm{Bq} \mathrm{g} \mathrm{g}^{-1}$ or $\mathrm{Bq}^{-1}$ ) & 1.6 & - & - & - & - \\
\hline
\end{tabular}


Table 2. Parameters (mean \pm ASE, $n=6-22$ ) of the whole-body uptake and/or depuration kinetics of ${ }^{134} \mathrm{Cs}$ in three bivalves species (G. pectinatum, I. isognomum and M. regula), one species of shrimp (P. stylirostris) and one alga (L. variegata) exposed to the radiotracers via seawater (A) and/or food (B) and/or sediment (C). Uptake parameters: $\mathrm{CF}_{\mathrm{ss}}$ : concentration factor at steady state ku: uptake rate constant $\left(\mathrm{d}^{-1}\right)$; E: exponential model. Depuration parameters: $\mathrm{A}_{0 \mathrm{~s}}$ and $\mathrm{A}_{01}$ : activity (\%) lost according to the short- and the long-lived exponential component, respectively; $\mathrm{T}_{\mathrm{b}^{1 / 2}}$ : biological half-life (d) $\left[\mathrm{T}_{\mathrm{b}^{1 / 2}}=\ln _{2 / \mathrm{ke}}\right] ; \mathrm{O}$ and $\mathrm{T}$ : one-component and two-components exponential models, respectively. ASE: asymptotic standard error; $\mathrm{R}^{2}$ : determination coefficient of kinetics.

\begin{tabular}{|c|c|c|c|c|c|c|c|c|c|c|c|}
\hline \multirow[t]{2}{*}{ Experiment } & \multirow[t]{2}{*}{ Species } & \multicolumn{4}{|l|}{ Uptake } & \multicolumn{6}{|l|}{ Loss } \\
\hline & & Model & $\mathrm{CF}_{s s} / \mathrm{TF}_{\mathrm{sS}} \pm \mathrm{ASE}$ & $\mathrm{k}_{\mathrm{u}} \pm \mathrm{ASE}$ & $\mathrm{R}^{2}$ & Model & $\mathrm{A0}_{\mathrm{s}} \pm \mathrm{ASE}$ & $\mathrm{Tb}^{1} / 2 \mathrm{~s} \pm \mathrm{ASE}$ & $\mathrm{A}_{1} \pm \mathrm{ASE}$ & $\mathrm{Tb}^{1 / 21} \pm \mathrm{ASE}$ & $\mathrm{R}^{2}$ \\
\hline \multirow[t]{5}{*}{ A. Seawater experiment } & G. pectinatum & $\mathrm{E}$ & $0.80 \pm 0.03^{* * *}$ & $0.19 \pm 0.04^{* * *}$ & 0.63 & $\mathrm{~T}$ & $46.6 \pm 5.5^{* * *}$ & $0.5 \pm 0.2^{* *}$ & $53.3 \pm 4.2^{* * *}$ & $22 \pm 3^{* * *}$ & 0.69 \\
\hline & I. isognomum & $\mathrm{E}$ & $1.29 \pm 0.52^{* * *}$ & $1.32 \pm 0.32^{* * *}$ & 0.62 & $\mathrm{~T}$ & $65.8 \pm 8.9^{* * *}$ & $3.2 \pm 1.2^{*}$ & $35.6 \pm 8.8^{* * *}$ & $405^{\mathrm{NS}}$ & 0.51 \\
\hline & M. regula & $\mathrm{E}$ & $1.21 \pm 0.04^{* * *}$ & $0.81 \pm 0.21^{* * *}$ & 0.63 & $\mathrm{~T}$ & $64.4 \pm 22^{* * *}$ & $5.6 \pm 3.3^{\mathrm{NS}}$ & $38.1 \pm 24.3^{\mathrm{NS}}$ & $138^{\text {NS }}$ & 0.68 \\
\hline & P. stylirostris & $\mathrm{E}$ & $8.26 \pm 0.21^{* * *}$ & $1.12 \pm 0.06^{* * *}$ & 0.93 & $\mathrm{O}$ & - & - & $81.8 \pm 1.3^{* * *}$ & $10 \pm 1^{* * *}$ & 0.94 \\
\hline & $L$ variegata & $\mathrm{E}$ & $15.6 \pm 1.0^{* * *}$ & $1.24 \pm 0.09^{* * *}$ & 0.83 & $\mathrm{O}$ & - & - & $96.5 \pm 1.8^{* * *}$ & $13 \pm 1^{* * *}$ & 0.88 \\
\hline \multirow[t]{4}{*}{ B. Food experiment } & G. pectinatum & - & - & - & - & $\mathrm{T}$ & $59.3 \pm 9.5^{* * *}$ & $0.4 \pm 0.2^{\mathrm{NS}}$ & $40.7 \pm 4.3^{* * *}$ & $89 \pm 55^{\mathrm{NS}}$ & 0.25 \\
\hline & I. isognomum & - & - & - & - & $\mathrm{T}$ & $90.9 \pm 1.0^{* * *}$ & $0.2 \pm 0.0^{* * *}$ & $9.1 \pm 0.5^{* * *}$ & $53 \pm 11^{* * *}$ & 0.99 \\
\hline & M. regula & - & - & - & - & $\mathrm{T}$ & $93.0 \pm 0.8^{* * *}$ & $0.2 \pm 0.0^{* * *}$ & $7.0 \pm 0.4^{* * *}$ & $39 \pm 8^{* * *}$ & 0.99 \\
\hline & P. stylirostris & - & - & - & - & $\mathrm{T}$ & $61.8 \pm 5.1^{* * *}$ & $1.2 \pm 0.2^{* * *}$ & $38.5 \pm 2.3^{* * *}$ & $16 \pm 3^{* * *}$ & 0.76 \\
\hline \multirow[t]{3}{*}{ C. Sediment experiment } & G. pectinatum & $\mathrm{E}$ & $0.020 \pm 0.001^{* * *}$ & $0.32^{\mathrm{NS}}$ & 0.53 & $\mathrm{~T}$ & $20.8 \pm 3.3^{* * *}$ & $0.6 \pm 0.4^{\mathrm{NS}}$ & $79.2 \pm 2.3^{* * *}$ & $37 \pm 2^{* * *}$ & 0.79 \\
\hline & I. isognomum & $\mathrm{E}$ & $0.084 \pm 0.003^{* * *}$ & $0.05 \pm 0.02^{* *}$ & 0.63 & $\mathrm{~T}$ & $34.8 \pm 11^{* *}$ & $4.2 \pm 2.5^{\mathrm{NS}}$ & $63.1 \pm 11.8^{* * *}$ & $58 \pm 25^{*}$ & 0.76 \\
\hline & M. regula & $\mathrm{E}$ & $0.080 \pm 0.005^{* * *}$ & $0.04 \pm 0.02^{\mathrm{NS}}$ & 0.37 & $\mathrm{~T}$ & $37.3 \pm 9.3^{* * *}$ & $3.3 \pm 1.7^{\mathrm{NS}}$ & $61.6 \pm 9.7^{* * *}$ & $47 \pm 15^{* *}$ & 0.74 \\
\hline
\end{tabular}

Probability (p) of the parameter estimation.

NS (Not significant): $\mathrm{p}>0.05, * \mathrm{p}<0.05, * * \mathrm{p}<0.01, * * * \mathrm{p}<0.001$. 
Table 3. Body distribution (\%; mean $\pm \mathrm{SD}$ ) of ${ }^{134} \mathrm{Cs}$ in three bivalve species (G. pectinatum, $I$. isognomum and M. regula) and one species of shrimp (P. stylirostris) during seawater (after 24-28 $\mathrm{d}$ of exposure and after 43-72 d of depuration), feeding (39-72 d after feeding the organisms with radiolabelled I. galbana for bivalves and M. edulis for shrimp) and sediment (after $35 \mathrm{~d}$ of exposure and after $49 \mathrm{~d}$ of depuration) experiments. Weights were expressed as a percentage of total mass. Weight proportions (\%) are provided such as the number of individuals (n) dissected each time (under brackets).

\begin{tabular}{|c|c|c|c|c|c|c|c|c|c|c|}
\hline \multirow[t]{3}{*}{ Species compartments } & \multicolumn{4}{|c|}{ Seawater experiment } & \multirow{2}{*}{\multicolumn{2}{|c|}{$\frac{\text { Food experiment }}{\text { End of loss }}$}} & \multicolumn{4}{|c|}{ Sediment experiment } \\
\hline & \multicolumn{2}{|c|}{ End of uptake } & \multicolumn{2}{|l|}{ End of loss } & & & \multicolumn{2}{|c|}{ End of uptake } & \multicolumn{2}{|l|}{ End of loss } \\
\hline & Weight (\%) & Distribution (\%) & Weight (\%) & Distribution (\%) & Weight (\%) & Distribution (\%) & Weight (\%) & Distribution (\%) & Weight (\%) & Distribution (\%) \\
\hline \multicolumn{11}{|l|}{ G. pectinatum } \\
\hline Whole soft-parts & $16.1 \pm 0.86$ & $64.0 \pm 12.6(5)$ & $11.0 \pm 2.3$ & $75.8 \pm 15.3(3)$ & $10.0 \pm 0.6$ & $85.7 \pm 7.9(6)$ & $10.0 \pm 1.1$ & $22.4 \pm 42.6(5)$ & $12.7 \pm 1.4$ & $6.3 \pm 1.1$ \\
\hline $\begin{array}{l}\text { Shell } \\
\text { I. isognomum }\end{array}$ & $83.9 \pm 0.86$ & $36.0 \pm 12.6(5)$ & $89.0 \pm 2.3$ & $24.2 \pm 15.3$ & $90.0 \pm 0.6$ & $14.3 \pm 7.9(6)$ & $90.0 \pm 1.1$ & $77.6 \pm 42.6(5)$ & $87.3 \pm 1.4$ & $93.7 \pm 1.1(5)$ \\
\hline Whole soft-parts & $11.3 \pm 2.5$ & $24.5 \pm 2.9(3)$ & 5.6 & $71.0(1)$ & $6.5 \pm 0.7$ & $24.9 \pm 34.7(3)$ & $3.2 \pm 0.7$ & $0.4 \pm 0.3(3)$ & $6.7 \pm 2.4$ & $1.6 \pm 0.2(3)$ \\
\hline $\begin{array}{l}\text { Shell } \\
\text { M. regula }\end{array}$ & \multicolumn{9}{|c|}{ M. regula } & $98.4 \pm 0.2(3)$ \\
\hline Whole soft-parts & $7.9 \pm 0.9$ & $17.1 \pm 4.8$ & $5.1 \pm 0.3$ & $58.6 \pm 38.1(3)$ & $3.98 \pm 0.9$ & $71.7 \pm 11.7$ & $3.0 \pm 0.9$ & $1.1 \pm 0.6$ & $5.0 \pm 2.1$ & $1.4 \pm 0.5$ \\
\hline \multirow[t]{2}{*}{ Shell } & $92.1 \pm 0.9$ & $82.9 \pm 4.8(3)$ & $94.9 \pm 0.3$ & $41.4 \pm 38.1(3)$ & $96.02 \pm 0.9$ & $28.3 \pm 11.7(3)$ & $97.0 \pm 0.9$ & $98.9 \pm 0.6(3)$ & $95.0 \pm 2.1$ & $98.6 \pm 0.5(3)$ \\
\hline & \multicolumn{2}{|c|}{ Beginning of loss (4d) } & \multicolumn{8}{|c|}{ End of loss (43d) } \\
\hline \multicolumn{11}{|l|}{ P. stylirostris } \\
\hline Cephalothorax & $45.3 \pm 4.4$ & $45.1 \pm 3.6(3)$ & $39.9 \pm 1.6$ & $18.1 \pm 3.8$ & $41.6 \pm 1.7$ & $24.7 \pm 8.5$ & n.a. & n.a. & n.a. & n.a. \\
\hline Abdomen $^{\mathrm{a}}$ & $54.7 \pm 4.4$ & $54.9 \pm 3.6(3)$ & $60.1 \pm 1.6$ & $82.9 \pm 3.8(3)$ & $58.4 \pm 1.7$ & $75.3 \pm 8.5(3)$ & n.a. & n.a. & n.a. & n.a. \\
\hline Muscle & $78.6 \pm 2.2$ & $87.5 \pm 1.8(3)$ & $75.1 \pm 9.2$ & $94.7 \pm 0.4(3)$ & $76.9 \pm 0.9$ & $72.8 \pm 22.4$ & n.a. & n.a. & n.a. & n.a. \\
\hline
\end{tabular}

n.a.: information not available.

a This compartment includes muscle, digestive tract and cuticle.

${ }^{\mathrm{b}}$ Deveined muscle. 
Table 4. Whole-body and tissues Concentration factors and Transfer factor (mean \pm SD, $n=3$ 5) of ${ }^{134} \mathrm{Cs}$ in three bivalve species (G. pectinatum, I. isognomum and M. regula) seawater (after $28 \mathrm{~d}$ of exposure) and sediment (after $30 \mathrm{~d}$ of exposure) experiments.

\begin{tabular}{|c|c|c|}
\hline \multirow[t]{2}{*}{ Species compartments } & \multirow{2}{*}{$\begin{array}{l}\text { Seawater exposure } \\
\text { CF }\end{array}$} & \multirow{2}{*}{$\frac{\text { Sediment exposure }}{\mathrm{TF}}$} \\
\hline & & \\
\hline \multicolumn{3}{|l|}{ G. pectinatum } \\
\hline Whole body & $0.8 \pm 0.3$ & $0.017 \pm 0.004$ \\
\hline Soft parts & $3.2 \pm 1.1$ & $0.004 \pm 0.002$ \\
\hline \multicolumn{3}{|l|}{ I. isognomum } \\
\hline Whole body & $1.5 \pm 0.5$ & $0.070 \pm 0.037$ \\
\hline Soft parts & $4.2 \pm 1.7$ & $0.006 \pm 0.003$ \\
\hline \multicolumn{3}{|l|}{ M. regula } \\
\hline Whole body & $1.3 \pm 0.5$ & $0.069 \pm 0.037$ \\
\hline Soft parts & $4.8 \pm 0.4$ & $0.009 \pm 0.000$ \\
\hline
\end{tabular}

